\title{
FAKTOR-FAKTOR YANG MEMPENGARUHI KETERANDALAN LAPORAN KEUANGAN PADA PEMERINTAH KOTA TANJUNGPINANG
}

\author{
Bambang Sambodo \\ Prodi S-1 Akuntansi Sekolah Tinggi Ilmu Ekonomi (STIE) Pembangunan Tanjungpinang \\ bambangsambodo@stie-pembangunan.ac.id \\ Yuyun Dwi Agustini \\ Prodi S-1 Akuntansi Sekolah Tinggi Ilmu Ekonomi (STIE) Pembangunan Tanjungpinang \\ yuyundwiagustini03@gmail.com
}

\begin{abstract}
Abstrak: Keterandalannya suatu Laporan Keuangan Kota Tanjungpinang pada dasarnya masih dipengaruhi oleh banyak faktor yang pelaksanaan program/kegiatan oleh Pemerintah Kota Tanjungpinang belum optimal, sehingga faktor-faktor tersebut sangat berpengaruh terhadap keandalan suatu laporan keuangan. Penelitian ini bertujuan untuk mengetahui pengaruh Pemanfaatan Teknologi Informasi, Pengendalian Intern Akuntansi, Pemahaman Standar Akuntansi Pemerintah, Pendidikan dan Pelatihan terhadap Keterandalan Laporan Keuangan pada Pemerintah Kota Tanjungpinang. Penelitian ini menggunakan metode kuantitatif dengan pengumpulan data menggunakan kuisioner. Sampel yang digunakan sebanyak 87 responden. Analisis data menggunakan SPSS Versi 25.0. Hasil dari penelitian ini Pemanfaatan Teknologi Informasi, Pengendalian Intern Akuntansi, Pemahaman Standar Akuntansi Pemerintah, Pendidikan dan Pelatihan secara parsial berpengaruh terhadap Keterandalan Laporan Keuangan dan secara simultan keempatnya juga berpengaruh terhadap Keterandalan Laporan Keuangan pada Pemerintah Kota Tanjungpinang.
\end{abstract}

Kata Kunci: Pemanfaatan Teknologi Informasi, Pengendalian Intern Akuntansi, Pemahaman SAP, Pendidikan dan Pelatihan, Keterandalan Laporan Keuangan

Abstract: The Tanjungpinang City Financial Statement's reliability is still influenced by many factors whose program/activity implementation by the Tanjungpinang City Government is not optimal, so these factors greatly influence the reliability of a financial report. The purpose of this study is to find out the effect of the use of information technology, accounting internal control, government accounting standards comprehension, education, and training on the reliability of financial reports in the Tanjungpinang City Government. This research uses quantitative methods in the form of survey research with questionnaires. The sample used in this study was 87 respondents and data analysis using SPSS version 25.0. Based on the result of research and discussion in this study, it can be concluded that the use of information technology, accounting internal control, government accounting standards comprehension, education, and training and Partially affect direct expenditure, and simultaneously, these four variables on the reliability of financial report in the Tanjungpinang City Government.

Keywords: The use of information technology, Accounting internal control, Government accounting standard comprehension, Education and Training, Reliability of financial report

\section{PENDAHULUAN}

Penelitian ini bertujuan untuk mengetahui

Pengaruh Pemanfaatan Teknologi Informasi,
Pengendalian Intern Akuntansi, Pemahaman

Standar Akuntansi Pemerintah, Pendidikan

dan Pelatihan terhadap Keterandalan Laporan 
Keuangan pada Pemerintah Kota Tanjungpinang.

Fenomena yang terjadi dalam perkembangan sektor publik di Indonesia saat ini yaitu, menguatnya tuntutan akuntabilitas atas lembaga-lembaga publik, baik pusat maupun daerah. Akuntabilitas diartikan sebagai bentuk kewajiban mempertanggungjawabkan keberhasilan atau kegagalan pelaksanaan misi organisasi dalam mencapai tujuan dan sasaran yang telah ditetapkan sebelumnya.

Informasi dalam laporan keuangan sesungguhnya bertujuan untuk memenuhi kebutuhan akan informasi keuangan dari semua kalangan seperti investor, masyarakat, dan juga pemerintah. Selanjutnya beberapa peraturan yang menjadi pedoman keuangan pemerintah daerah yakni (1) Peraturan Pemerintah Nomor 71 Tahun 2010 tentang Standar Akuntansi Pemerintahan,

Peraturan Menteri Dalam Negeri Nomor 21

Tahun 2011 tentang Perubahan Kedua atas Peraturan Menteri Dalam Negeri Nomor 13 Tahun 2006 tentang Pedoman Pengelolaan Keuangan Daerah, kemudian (3) Peraturan Menteri Dalam Negeri Nomor 64 Tahun 2013 tentang Penerapan Standar Akuntansi Pemerintah Berbasis Akrual pada Pemerintah Daerah.

Peraturan Pemerintah Nomor 71 Tahun 2010 tentang Standar Akuntansi Pemerintahan salah satu tujuan laporan keuangan adalah menyediakan informasi yang menyangkut posisi keuangan, dan kualitas informasi yang andal yang dapat menjadikan informasi dalam posisi laporan keuangan pemerintah mempunyai nilai, manfaat, penyajian jujur, dapat diverifikasi, serta netralitas. Yang dimaksud andal yaitu bahwa informasi yang andal dalam laporan keuangan bebas dari pengertian yang menyesatkan dan kesalahan material, informasi dalam laporan keuangan tersebut menyajikan fakta secara jujur serta dapat diverifikasi. Informasi mungkin relevan, tetapi jika hakikatnya atau dalam penyajiannya tidak dapat diandalkan maka penggunaan informasi tersebut secara potensial dapat menyesatkan. Kualitas informasi yang andal yang dapat menjadikan informasi dalam laporan keuangan pemerintah mempunyai nilai, manfaat, penyajian jujur, dapat diverifikasi, serta netralitas.

Faktor-faktor penentu pada uraian diatas dalam prakteknya tidak sejalan sesuai yang diharapkan dengan kondisi yang terjadi saat ini, sehingga mengakibatkan laporan keuangan yang disajikan tidak dapat diandalkan. Fenomena yang terjadi pada Pemerintah Kota Tanjungpinang yakni:

Hal pertama adalah terletak pada pemanfaatan teknologi informasi. Teknologi dipandang sebagai alat yang digunakan oleh individu maupun kelompok untuk menyelesaikan tugas-tugasnya. Kewajiban pemanfaatan teknologi informasi oleh Pemerintah Daerah diatur dalam Peraturan ("Undang-undang RI No. 19 tahun 2016 
tentang Informasi dan Transaksi Elektronik," 2016) tentang perubahan atas UU Nomor 11 Tahun 2008 tentang Informasi dan Transaksi Elektronik, walaupun secara umum telah banyak diketahui manfaat yang ditawarkan oleh suatu teknologi informasi antara lain kecepatan pemrosesan transaksi dan penyiapan laporan, keakuratan perhitungan, penyimpanan data dalam jumlah besar, namun pengimplementasian teknologi informasi tidaklah murah. Terlebih jika teknologi informasi yang ada belum mampu dimanfaatkan secara maksimal maka implementasi teknologi menjadi sia-sia dan semakin mahal.

Faktor lain yang dapat mempengaruhi keterandalan laporan keuangan adalah Pengendalian Intern Akuntansi. Menurut (Peraturan Pemerintah Nomor 71 Tahun 2010 tentang Standar Akuntansi Pemerintah, 2012) Pengendalian Intern sebagaimana dimaksud merupakan proses yang dirancang untuk memberikan keyakinan yang memadai mengenai pencapaian tujuan Pemerintah Daerah yang tercemin dari keandalan laporan keuangan, efisiensi, dan efektivitas pelaksanaan program dan kegiatan serta dipatuhinya peraturan perundang-undangan.

Selain Pemanfaatan Teknologi dan Pengendalian Intern Akuntansi, faktor lain yang dapat mempengaruhi keterandalan laporan keuangan adalah Standar Akuntansi Pemerintahan, Menurut (Peraturan Pemerintah Nomor 71 Tahun 2010 tentang Standar Akuntansi Pemerintah, 2012)
Standar akuntansi pemerintahan, yang di singkat SAP selanjutnya oleh Pemerintah menerapkan SAP Berbasis Akrual, yaitu prinsip-prinsip akuntansi yang di terapkan dalam menyusun dan menyajikan laporan keuangan pemerintah. Dalam hal ini OPD Kota Tanjungpinang sedang mengalami masa transisi yakni perubahan Peraturan Pemerintah Nomor 24 Tahun 2005 menjadi Peraturan Pemerintah Nomor 71 Tahun 2010 terkait Standar Akuntansi Pemerintah (SAP).

Hal terakhir yang mempengaruhi keterandalan laporan keuangan adalah Pendidikan dan Pelatihan, menurut (Saleh, Islamy, Zauhar, \& Supriyono, 2013), pendidikan dan pelatihan (Diklat) adalah sebagai salah satu sarana yang dapat difungsikan untuk melakukan program penguatan dan improvisasi kompeten personal bagi sumber daya aparatur, terutama bagi seseorang yang berstatus sebagai PNS.

Penelitian ini dilakukan untuk mengetahui apakah terdapat pengaruh antara Pemanfaatan Teknologi Informasi, Pengendalian Intern Akuntansi, Pemahaman Standar Akuntansi Pemerintah, Pendidikan dan Pelatihan terhadap Keterandalan Laporan Keuangan pada Pemerintah Kota Tanjungpinang. 


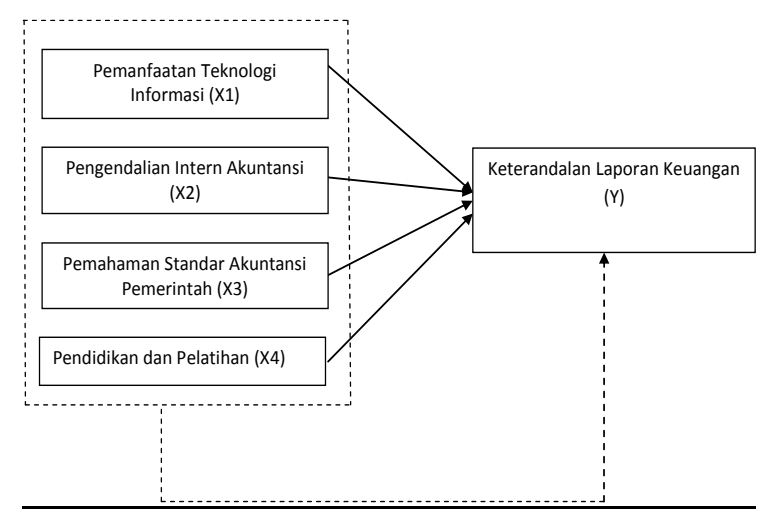

Sumber : Konsep yang dikembangkan untuk

penelitian 2019

Gambar 1. Kerangka Pemikiran

Hipotesis dalam penelitian ini adalah:

H1: Pemanfaatan Teknologi Informasi berpengaruh terhadap Keterandalan Laporan Keuangan pada Pemerintah Kota Tanjungpinang.

$\mathrm{H} 2$ : Pengendalian Intern Akuntansi berpengaruh terhadap Keterandalan Laporan Keuangan pada Pemerintah Kota Tanjungpinang.

H3: Pemahaman Standar Akuntansi Pemerintah berpengaruh terhadap Keterandalan Laporan Keuangan pada Pemerintah Kota Tanjungpinang

H4: Pendidikan dan Pelatihan berpengaruh terhadap Keterandalan Laporan Keuangan pada Pemerintah Kota Tanjungpinang.

H5: Pemanfaatan teknologi informasi, pengendalian intern akuntansi, pemahaman standar akuntansi pemerintahan, pendidikan dan pelatihan berpengaruh terhadap Keterandalan Laporan Keuangan pada Pemerintah Kota Tanjungpinang.

\section{METODE PENELITIAN}

Penelitian ini dilakukan di 29 Organisasi Perangkat Daerah Pemerintah Kota
Tanjungpinang. jenis penelitian ini menggunakan metodel penelitian kuantitatif.

Jenis data yang digunakan dalam penelitian yaitu data primer. Teknik pengumpulan data yang digunkan dalam penelitian ini adalah menggunakan studi pustaka dan kuisioner.

Populasi dari penelitian ini adalah aparatur sipil negara yang bekerja pada organisasi perangkat daerah Pemerintah Kota Tanjungpinang yang berhubungan langsung dengan pengelolaan keuangan, berjumlah 142 orang. Sampel berjumlah 29 orang yang didapat dengan menggunakan metode purposive sampling, yaitu orang-orang yang berkaitan langsung dengan verifikasi dan pencatatan transaksi keuangan.

Teknik analisa data yang dipergunakan dalam penelitian ini yaitu menggunakan Software komputer SPSS (Statistical Program for Social Science) versi 25.0 for windows, dengan skala likert. Dengan tahapan sebagai berikut:

1. Uji kualitas data (Uji validitas dan reliabilitas)

2. Uji Asumsi Klasik

3. Analisis Regresi Berganda

4. Pengujian hipotesis
a. Uji Parsial (Uji-t)
b. Uji Simultan (Uji-F)

5. Koefisien Determinasi $\left(\mathrm{R}^{2}\right)$, digunakan untuk mengetahui persentase sumbangan pengaruh variabel independen $(\mathrm{X})$ secara serentak terhadap variabel dependen $(Y)$. 


\section{HASIL DAN PEMBAHASAN}

Hasil yang tedapat pada uji validitas dan reliabilitas menggunakan perhitungan SPSS versi 25,0 dinyatakan seluruh instrument valid dan reliable. Hasil yang tedapat pada uji data statistik dengan menggunakan Histogram menunjukkan bahwa tidak mengalami kemencengan baik kiri atau kanan, atau dengan kata lain grafik dalam keadaan seimbang dan untuk grafik Normal P-P Plot menunjukkan bahwa titik-titik plotnya berada atau mengikuti arah garis diagonal. Pada uji One Sample KolmogorovSmirnov Test menunjukkan bahwa nilai signifikansi yaitu $0,200>0,05$. Dari hasil tersebut bahwa seluruh komponen berdistribusi normal.

Uji Multikolinearitas menunjukkan bahwa nilai tolerance $>0,1$ dan nilai $\mathrm{VIF}<10$ pada setiap variabel yang diuji. Dengan nilai Pemanfaatan TI, pengendalian intern akuntansi, pemahaman SAP, pendidikan dan pelatihan, masing-masing variabel memiliki nilai tolerance sebesar $0,404,0,381,0,911$, 0,617 yang mana $>0,1$ dan nilai VIF masingmasingf variabel sebesar 2,476, 2,625, 1,098, 1,622 yang mana < 10 sehingga dapat disimpulkan bahwa tidak terjadi Multikolinearitas.

Uji heteroskedastisitas dengan grafik scatteplot menunjukkan bahwa titik-titik menyebar diatas dan dibawah sumbu $\mathrm{Y}$ dan disempurnakan melalui uji glejser yang mana nilai signifikansinya $>0,05$ dan pada olahan data SPSS versi 25,0 diketahui nilai signifikansi dari masing-masing variabel yaitu: $0,607,0,589,0,868,0,555,0,881$ lebih besar dari 0,05 maka disimpulkan tidak terjadi heteroskedaditas.

Uji autokorelasi dengan menggunakan uji Durbin-Watson (DW test) menunjukkan bahwa nilai yang di hasilkan sebesar 1,522, yang berarti nilai $\mathrm{DW}<2$ maka dapat disimpulkan bahwa data tidak terjadi autokorelasi.

Pada Analisis Regresi Linear Berganda diperoleh persamaan sebagai berikut:

Tabel 1. Output Analisis Regresi Linear Berganda Coefficients ${ }^{\mathrm{a}}$

\begin{tabular}{|c|c|c|c|}
\hline \multirow{2}{*}{\multicolumn{2}{|c|}{ Model }} & \multicolumn{2}{|c|}{ Unstandardized Coefficients } \\
\hline & & $\mathrm{B}$ & Std. Error \\
\hline \multirow[t]{5}{*}{1} & (Constant) & $-9,808$ & 1,783 \\
\hline & Total_X1 & ,343 & 056 \\
\hline & Total_X2 & , 145 & ,043 \\
\hline & Total_X3 &, 080 & 035 \\
\hline & Total_X4 & , 130 &, 060 \\
\hline
\end{tabular}

a. Dependent Variable: Total_Y

Sumber : Output SPSS Versi 25

$Y=-9,808+0,343 X 1+0,145 X 2+0,080 X 3$

$+0,130 X 4+\mathrm{e}$

Tabel 2. Output Uji Parsial (Uji-t)

\begin{tabular}{|l|l|r|r|}
\hline \multicolumn{2}{|c|}{ Coefficients $^{\text {a }}$} \\
\hline \multicolumn{2}{|c|}{ Model } & T & Sig. \\
\hline \multirow{3}{*}{1} & (Constant) & $-5,501$ &, 000 \\
\cline { 2 - 4 } & Total_X1 & 6,139 &, 000 \\
\cline { 2 - 4 } & Total_X2 & 3,341 &, 001 \\
\cline { 2 - 4 } & Total_X3 & 2,308 &, 024 \\
\cline { 2 - 4 } & Total_X4 & 2,145 &, 035 \\
\hline a. Dependent Variable: Total_Y & \\
\hline
\end{tabular}

Sumber : Output SPSS Versi 25 
Dari tabel diatas dapat disimpulkan bahwa Pemanfaatan Teknologi Informasi dengan nilai sig $0,000<0,05$ dan nilai thitung $6,139>$ $t_{\text {tabel }} 1,663$ yang berarti Pemanfaatan Teknologi Informasi secara parsial berpengaruh terhadap Keterandalan Laporan Keuangan.

Pengendalian Intern Akuntansi dengan nilai sig $0,001<0,05$ dan nilai $t_{\text {hitung }} 3,341>$ $t_{\text {tabel }} 1,663$ yang berarti Pengendalian Intern Akuntansi secara parsial berpengaruh terhadap Keterandalan Laporan Keuangan.

Pemahaman Standar Akuntansi Pemerintah dengan nilai sig $0,024<0,05$ dan nilai $t_{\text {hitung }} 2,308>t_{\text {tabel }} 1,663$ yang berarti Pemahaman Standar Akuntansi Pemerintah secara parsial berpengaruh terhadap Keterandalan Laporan Keuangan.

Pendidikan dan Pelatihan dengan nilai sig $0,035<0,05$ dan nilai $t_{\text {hitung }} 2,145>t_{\text {tabel }} 1,663$ yang berarti Pendidikan dan Pelatihan secara parsial berpengaruh terhadap Keterandalan Laporan Keuangan.

Tabel 3. Output Uji Simultan (Uji-F) ANOVA $^{\mathrm{a}}$

\begin{tabular}{|l|l|l|c|}
\hline \multicolumn{2}{|c|}{ Model } & F & Sig. \\
\hline 1 & Regression & 67,306 &, $000^{\mathrm{b}}$ \\
\cline { 2 - 4 } & Residual & & \\
\hline & Total & & \\
& & & \\
&
\end{tabular}

a. Dependent Variable: Total_Y

b. Predictors: (Constant), Total_X4,

Total_X3,Total_X1, Total_X2

Sumber : Output SPSS Versi 25

Dari uji simultan table diatas dapat dibuktikan nilai sig $0,000<0,05$ dan $F_{\text {hitung }}>$
$F_{\text {tabel }}(67,306>2,716)$ sehingga dapat disimpulkan bahwa Variabel Pemanfaatan Teknologi Informasi, Pengendalian Intern Akuntansi, Pemahaman Standar Akuntansi Pemerintahan, Pendidikan dan Pelatihan berpengaruh secara simultan terhadap variabel Keterandalan Laporan Keuangan.

Tabel 4 Output $\mathbf{R}^{2}$

Model Summary ${ }^{b}$

\begin{tabular}{|l|l|}
\hline Model & \multicolumn{2}{|c|}{ Adjusted R Square } \\
\hline 1 & \\
\hline
\end{tabular}

a. Predictors: (Constant), Total_X4,

Total_X3, Total_X1, Total_X2

b. Dependent Variable: Total_Y

Sumber : Output SPSS Versi 25

Dari uji table diatas dapat disimpulkan bahwa nilai Adjusted $R$ Square sebesar 75,5\% sedangkan sisanya $24,5 \%$ dijelaskan oleh variabel lain yang tidak dimasukkan dalam penelitian ini.

\section{KESIMPULAN}

Berdasarkan hasil dan pembahasan yang telah dilakukan dalam penelitian ini, dapat diambil kesimpulan oleh peneliti sebagai berikut:

1. Secara parsial variabel pemanfaatan teknologi informasi berpengaruh terhadap variabel keterandalan laporan keuangan sebesar $t_{\text {hitung }}>t_{\text {tabel }}(6,139>1,663)$ dan signifikan $(0,000<0,05)$.

2. Secara parsial variabel pengendalian intern akuntansi berpengaruh terhadap variabel keterandalan laporan keuangan sebesar $t_{\text {hitung }}>\mathrm{t}_{\text {tabel }}(3,341>1,663)$ dan signifikan $(0,001<0,05)$. 
3. Secara parsial variabel pemahaman standar akuntansi pemerintahan berpengaruh terhadap variabel keterandalan laporan keuangan sebesar $t_{\text {hitung }}>t_{\text {tabel }}(2,308>1,663)$ dan signifikan $(0,024<0,05)$.

4. Secara parsial variabel pendidikan dan pelatihan berpengaruh terhadap variabel keterandalan laporan keuangan sebesar $t_{\text {hitung }}>t_{\text {tabel }}(2,145>1,663)$ dan signifikan $(0,035<0,05)$.

5. Secara simultan variabel pemanfaatan teknologi informasi, pengendalian intern akuntansi, pemahaman standar akuntansi pemerintahan, pendidikan dan pelatihan berpengaruh simultan terhadap keterandalan laporan keuangan pada pemerintah kota tanjungpinang. sebesar $f_{\text {hitung }}>\mathrm{f}_{\text {tabel }}(67,306>2,716)$ dan signifikan $(0,000<0,05)$.

Dari hasil uji Koefisien Determinasi $\left(\mathrm{R}^{2}\right)$ mempunyai nilai sebesar 0,755 yang artinya, variabel pemanfaatan teknologi informasi, pengendalian intern akuntansi, pemahaman standar akuntansi pemerintahan, pendidikan dan pelatihan secara simultan memiliki pengaruh yang kuat terhadap keterandalan laporan keuangan pada pemerintah kota tanjungpinang yakni sebesar 75,5\% sedangkan sisanya $24,5 \%$ dipengaruhi oleh variabel lain diluar penelitian ini.

\section{SARAN}

Berdasarkan kesimpulan di atas, adapun saran yang dapat penulis sampaikan adalah sebagai berikut:

1. Bagi OPD Kota Tanjungpinang, agar pemanfaatan teknologi dalam hal pengelolaan data keuangan yang telah menggunakan software sesuai peraturan lebih ditingkatkan lagi dan perlu meningkatkan pendampingan dalam operasional sistem perangkat lunak pemerintah daerah sehingga laporan keuangan yang dihasilkan semakin andal. Diharapkan untuk setiap instansi lebih meningkatkan lagi kualitas sumber daya manusia dengan melaksanakan berbagai kegiatan yang dapat meningkatkan skill para staf atau pegawai dari masing-masing instansi.

2. OPD Kota Tanjungpinang diharapkan dalam melaksanakan pengendalian internal betul-betul menjunjung tinggi kejujuran.

3. Diharapkan untuk setiap OPD lebih meningkatkan lagi kualitas sumber daya manusia dengan melaksanakan berbagai pendidikan dan pelatihan (DIKLAT) atau kegiatan yang dapat meningkatkan skill para staf atau pegawai dari masing-masing instansi.

4. Bagi peneliti selanjutnya sebaiknya menambah jumlah responden penelitian, mengingat dalam penelitian ini hanya 87 orang responden dalam 29 OPD yang dijadikan objek penelitian. Sebaiknya 
menambah jumlah instansi agar sampel yang dijadikan responden bersifat representatif.

5. Mempertimbangkan variabel-variabel lain yang diduga berpengaruh terhadap Keterandalan Laporan Keuangan, misalnya komitmen manajemen maupun Kualitas Sumber Daya Manusia.

\section{DAFTAR PUSTAKA}

Dantes, N., 2012. Metode Penelitian, Yogyakarta; CV. Andi Offset.

Peraturan Pemerintah Nomor 71 Tahun 2010 tentang Standar Akuntansi Pemerintah. (2012). Bandung: Fokusmedia.

Prastowo, A., 2011. Memahami metodemetode penelitian. Jogjakarta: Ar-Ruzz
Media.

Saleh, C., Islamy, M.I., Zauhar, S. and Supriyono, B., 2013. Pengembangan Kompetensi Sumber Daya Aparatur. Universitas Brawijaya Press.

Sedarmayanti, Hidayat, S. 2011. Metodologi Penelitian-cetakan II. Bandung: CV. Mandar Maju.

Sudjatmoko. 2015. Leader Transformasional. Jawa Tengah: Panembahan Senopati.

Sugiyono. 2011. Metode Penelitian Administrasi dilengkapi dengan Metode $R \& D$. Bandung: Alfabeta, CV.

Sugiyono. 2017. Metode Penelitian Kuantitatif, Kualitatif, dan $R \& D$ cetakan ke-26. Bandung: ALFABETA, $\mathrm{CV}$.

Undang-undang RI No. 19 tahun 2016 tentang Informasi dan Transaksi Elektronik. (2016). Kemenkumham. 